\title{
Occurrence of Bioturbation Structures at Estuarine Environment of the Sunderbans, Eastern India
}

\author{
Gautam Kumar Das \\ Department of Chemical Engineering \\ Jadavpur University, Kolkata- 700 075, India \\ Email: gautamkrdas@yahoo.com
}

\begin{abstract}
Bioturbation structures produced by the interaction of living organisms and soft sediments have manifested itself in the wide range of forms like tracks and trails, footprints, burrows, mounds, pellets etc. in different geomorphic domains of mesomacrotidal estuarine environment of Sunderbans. Study of behavioural pattern of these organisms through bioturbation structures helps geologists in deciphering the environmental condition prevalent during the intervening period of deposition of soft sediments and their lithification. They may be of lesser magnitude but the processes of bioturbation have the potentiality to alter depositional sequences and sediment chemistry through the process of exhumation and subsurface mixing of sediments as evidenced in cases of burrows in the intertidal muddy flats of Sunderbans. The present paper deals with the interactions of macrobenthos and other organisms with the estuarine sediments of Sunderbans leading to a wide variety of bioturbation structures and also describes their geometry and significance.
\end{abstract}

Key Words: Bioturbation structures, track, trails, foot prints, fin marks, mounds, press marks, burrows, tubes, pits, borings.

\section{Introduction}

Organization of sediments by physical processes in the tidal environment and the physical sedimentary structures formed thereby have been observed as common phenomena from the sedimentological point of view at coastal environment. But disturbance-induced modifications in the sedimentary deposits due to activity of living organisms seem to be no less important in the exposed and sheltered intertidal zones of the deltaic Sunderbans. Intertidal zones of the estuarine Sunderbans (Fig. 1) including river banks, natural levees, point bars and mid channel bars inundated twice daily in the semi-diurnal situations (Das, 2015) are scattered with several bioturbation structures. The present paper deals with the interactions of macrobenthos and sediments leading to bioturbational structures of a wide variety of forms. Benthic animals have major effects not only on the physical properties of sediments, but also on sediment chemistry (Raffaelli and Hawkins, 1996). Many macrobenthos, by their physical presence, stabilize sediments by inhibiting erosion. Mucus production of most infaunal species adds substantially to sediment binding (Paterson et al., 1986). Contrary to this, destabilization of sediment is caused by deposit feeders during crawling, browsing and other modes of locomotion when the surface sediments get loose and become susceptible to erosion. 


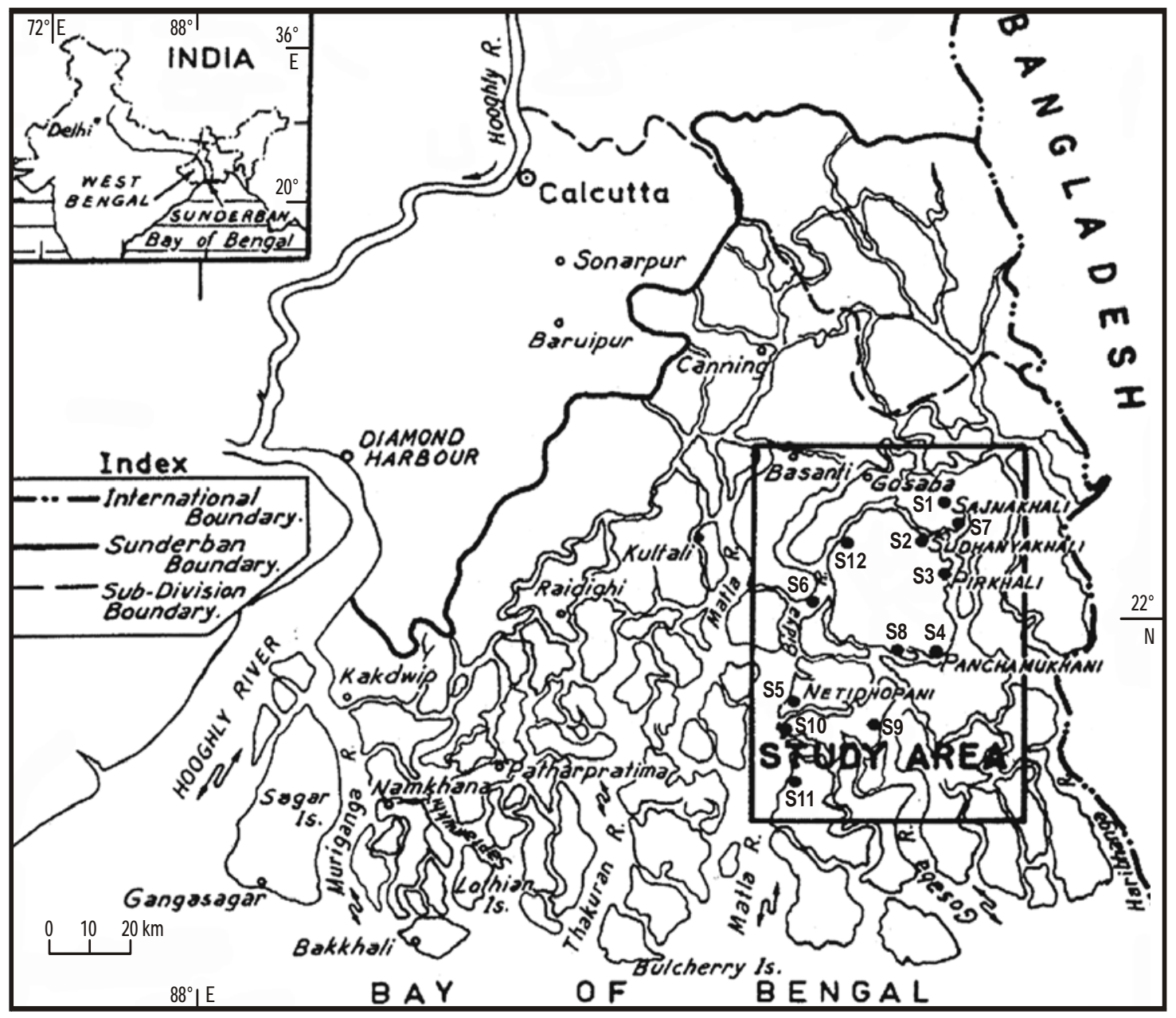

Fig.1: Map of the Sunderbans showing study area and sampling locations.

As defined by Frey (1975) bioturbation structures or libensspurens (Richter, 1936; 1937; 1952) are biogenic sedimentary structures that disrupt physical stratifications or rearrange sediment fabric by the activity of organisms in the form of tracks, trails, burrows and other similar structures. These features are described as 'trace fossils' when recorded from ancient rocks. As these structures are produced by the activity of living organisms within or on the sediments they produce various sculptures on sediment surface and may even lead to complete or partial destruction and reformation of physically produced primary or secondary structures.

Benthic animal communities are essentially environment sensitive and so are the bioturbation structures produced by them. These structures are further important for being autochthonus. Barring their ecological and environmental significance (Seilacher, 1953) these biogenic structures are good indicators of bathymetry (Seilacher, 1958; 1964) and rate of sedimentation (Reineck, 1958). They become more abundant and complicated in areas of slow rate of sedimentation. In areas of rapid sedimentation or erosion, on the contrary, bioturbations are fewer, less intense and simple. 
Open access e-Journal

Earth Science India, eISSN: $0974-8350$

Vol. 9 (I), January, 2016, pp. 1 - 20

http://www.earthscienceindia.info/

\section{Previous Work}

The density of animal population vis-a-vis density of bioturbation structure depends mostly on i) oxygen content of the substrate and of the ambient environment based on water circulation; Schmidt, 1958; ii) availability of food iii) grain size controlled by hydrodynamic conditions; Reineck, 1967; Dorjes et al., 1969 and iv) conditions of sedimentation (Reineck, 1967; Hertweck, 1975). The role of animal-sediment interactions, biogenic alteration of recent marine and fresh water deposits as well as of their ancient counterparts have been excellently summed up by McCall and Tevesz (1982). Frey and Howard (1969), Hertweck (1975), Basan and Frey (1977) differentiated various coastal zones based on bioturbation structures. The classical work of Frey (1975) on trace fossils provides an important document for working with bioturbation structures of both recent and recent origin.

Studies on estuarine systems are quite common. But complete works on the bioturbation structures of the estuarine environments are scare in the geological literature. With a view to understand the totality of the bioturbation structures involved in the marginal bars, mid channel bars, point bars of the tidal rivers, tidal creeks of an estuary, Sunderbans of India has been chosen for the study. Although it is a very dynamic system helpful for understanding the tidal sedimentation processes and history of evolution of the Gangetic delta as a whole no previous work on bioturbation structures of the Sunderbans exists.

\section{Methodology}

Anaesthetization, narcotisation, fixation and preservation of the animals which are responsible for the bioturbation structures, are very important for their proper identification. Biological samples of macrobenthic animals were collected in the field. Benthic animals living in soft sand and mud in the point bars, marginal bars and mid channel bars were collected by careful digging and sifting of the sediments. Burrowing species like copepods, sea anemones, polychaetes, crabs etc. were often be located by seeing the holes on the sediment substratum. Specimens collected for the identification were captured by simple direct means, often were collected simply by hands or using forceps and sometimes techniques or equipments had to be improvised for capturing some animals in particular area of the biotopes. Collected organic specimens particularly animals were anaesthetized before fixation to avoid distortion of the body due to musculature contraction. This was achieved by immersion in a $7 \%$ solution of $\mathrm{MgCl}_{2}$. The animals were then fixed in $5 \%$ neutral formalin solution when the animals no longer responded to probing they could be killed and then transferred to $70 \%$ alcohol for preservation. The preserved specimens were carried to the respective section of Zoological Survey of India for proper identification. The fauna were identified taking help of the scientists of the Zoological Survey of India. Measurements of the elements of both physical and bioturbation structures were taken with precision. Important bioturbation features were photographed for documentation. L-shaped trenches were dug to study the internal bioturbation structures including burrows and tubes.

\section{Basis of Adopted Classification of Bioturbation Structures}

Various attempts have been made to classify bioturbation structures as per need and purpose with which they have been employed (e.g. Reineck and Singh, 1980). In the present work the author prefers to classify the various bioturbation structures into a three-fold classification after Hertweck (1970). These are A) surface libensspuren B) internal libensspuren and C) dwelling structures. All the bioturbation structures encountered in the different sub-environments of the present field can be conveniently grouped as per the above 
scheme (Figs. 2 and 3). The author is, however, aware of the critique of Reineck and Singh (1980) regarding the demerit of this classification to differentiate the structures. Reineck and Singh (1980) argue that as the benthic animals may move within sediment along the bedding planes, the internal bioturbation structures may be misinterpreted as surface bioturbation structures in ancient sedimentary rocks if the bedding planes come to exposure after erosion. This limitation, however, is not applicable to the present study as it is employed in the recent sedimentary deposits where surface and internal processes can be easily distinguished.

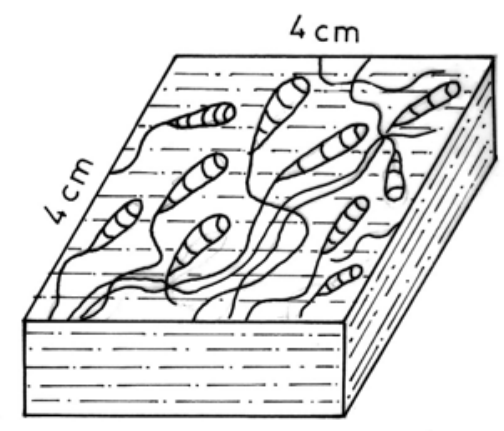

\section{A. Grazing traces of Cerithidia sp.}

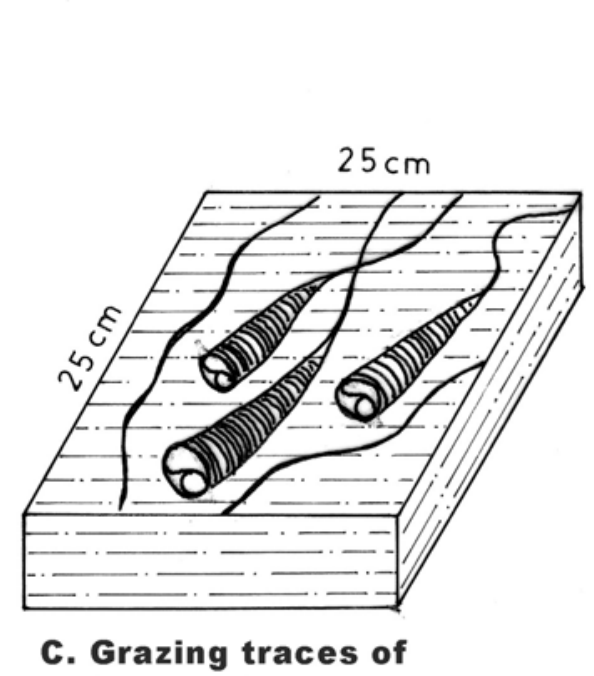

C. Grazing traces of
Telescopium $\mathrm{sp.}$

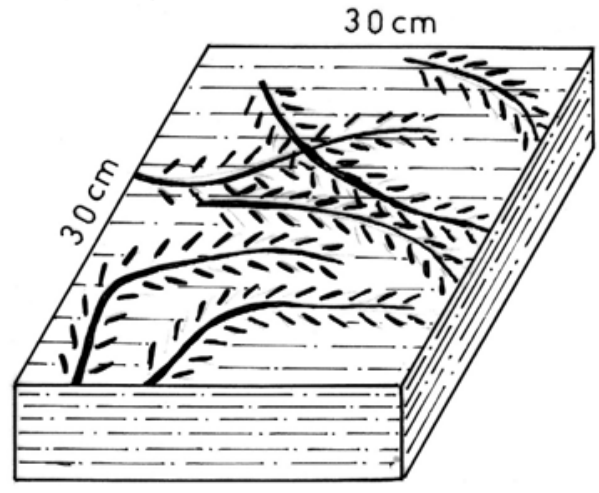

B. Crawling traces \& Fin marks of Boleophthalmus sp.
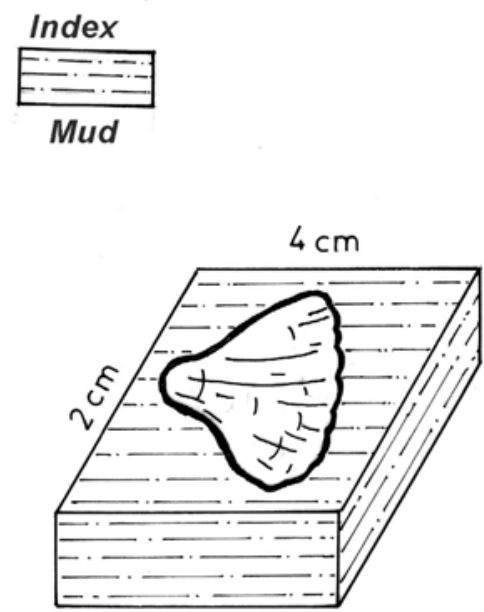

D. Press mark of Anadara sp.

Fig. 2: Surface bioturbation structures on the intertidal mudflats of the Sunderbans.

The large variety of bioturbation structures when analysed from the sedimentological point of view reveals that the shape of organisms, activity of their functional organs and behaviour of organisms determine the actual details of the bioturbation structures. Furthermore, the animals have their preferential habitats based on sandy and muddy substrates. Accordingly, the nature of biogenic bed roughness viz, mounds, tubes, trails, pits etc. is the surficial expression of the nature of bioturbational activities in sediments. Table- 1 
Open access e-Journal

Earth Science India, eISSN: $0974-8350$

Vol. 9 (I), January, 2016, pp. 1 - 20

http://www.earthscienceindia.info/

depicts the interrelations among sedimentary facies, bed roughness and bioturbation structure of the present study area i.e. Sunderbans.

Table-1: Sedimentary facies, bed roughness and their relations with bioturbation structures.

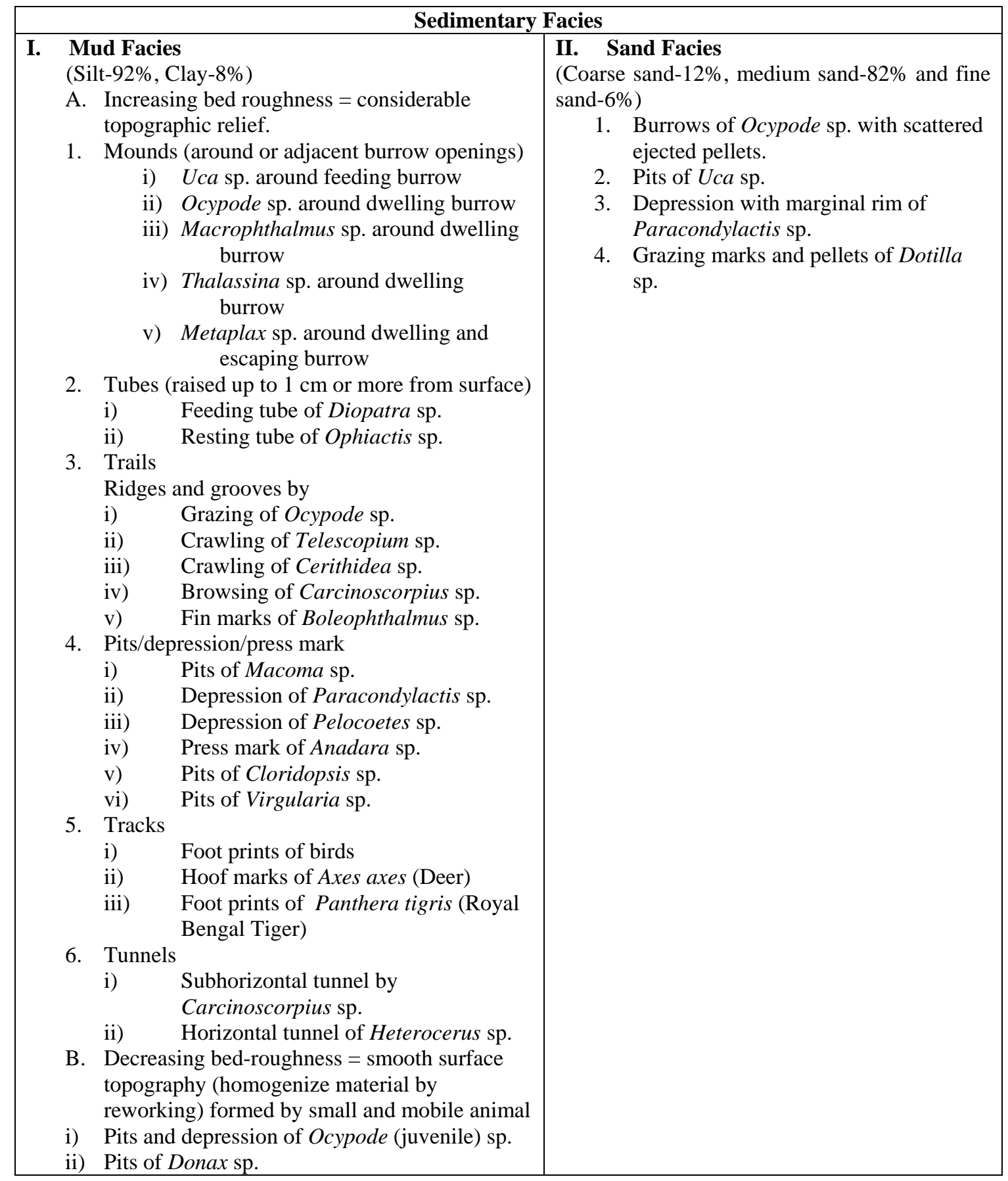




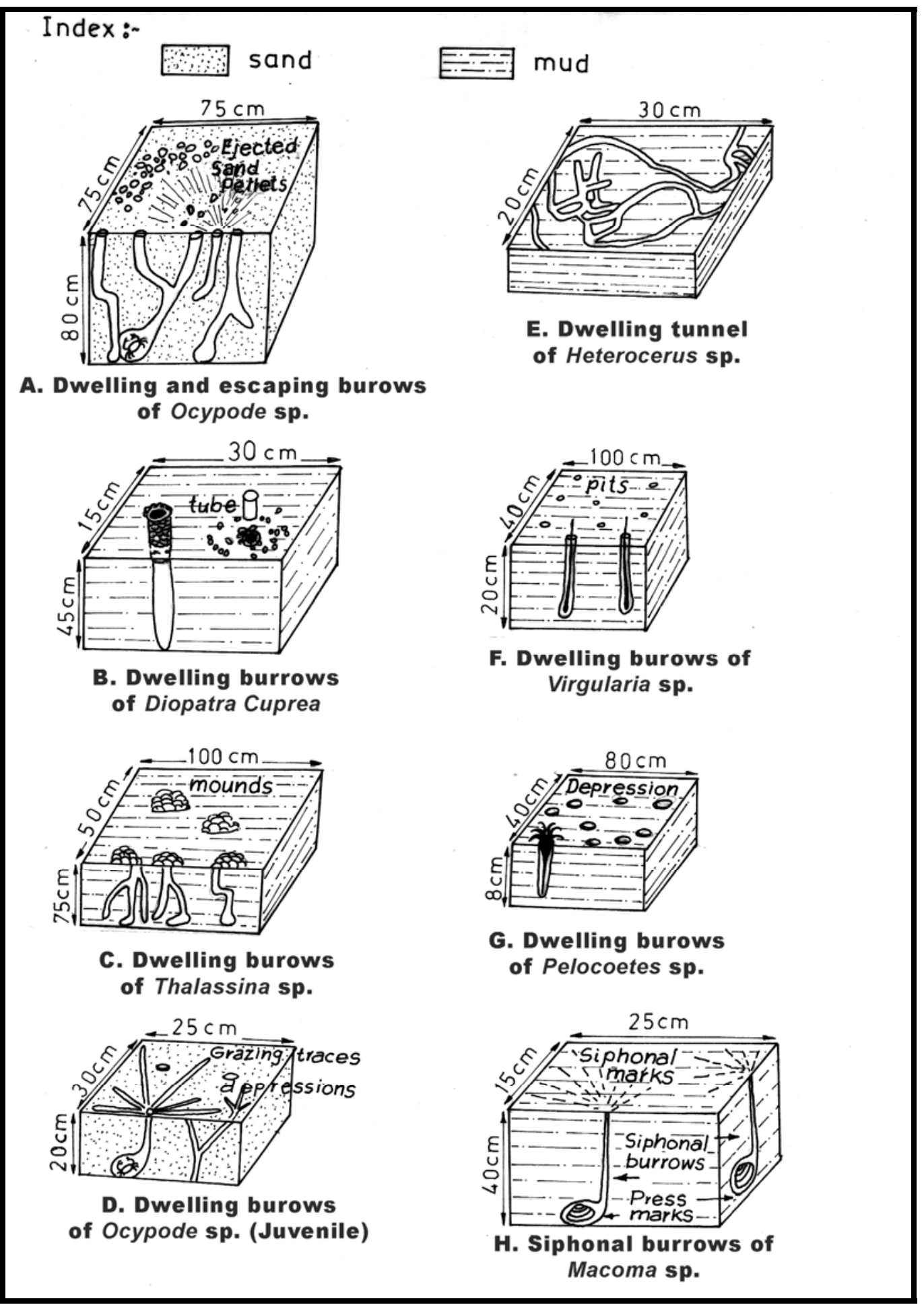

Fig. 3: Dwelling bioturbation structures in the intertidal mudflat of the Sunderbans. 


\section{The Classification}

\section{Surface Bioturbation Structures}

Bioturbation structures that are recognisable on the surface of sedimentary deposits can be sub-divided into the following types based chiefly on ethology i.e. on the behaviour of organisms as reflected from their traces (Seilacher, 1953).

Tracks: Discontinuous marks of footprints left over on sandy and muddy surface (e.g. bird foot prints, deer hoof marks and foot prints of tigers).

\section{Bird Foot Prints}

The Hooghly-Matla estuarine complex of the Sunderbans is famous for the stop-over of certain aves community. These birds often move on the sandy and muddy surfaces of the intertidal deposits in search of food. As a result bird foot prints are quite common in areas where there is greater population of benthic animals communities. The foot prints of birds may continue for few metres to several hundred metres; may be rectilinear to curvilinear in pattern. Fig. 4 depicts a series of bird foot prints on the mudflats of Matla River where the direction of the track indicating movement of birds from south to north can be easily traced. The track maintains a steady trend without showing much dislocation.

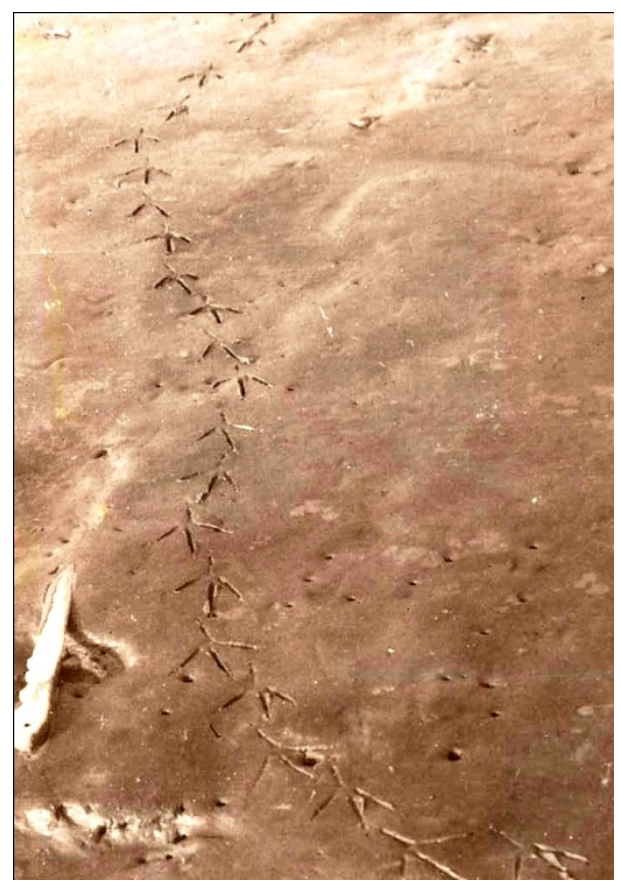

Fig. 4: Bird foot prints on the mudflats of Bhubaneswari. The track can be traced from the bottom to top of the photograph. Knife is $26 \mathrm{~cm}$.

\section{Hoof Prints of Deer (Axes axes)}

The intertidal mudflats in and around the river banks with dense mangrove vegetation at Dhanchi reserve forest bear evidences of a number of foot print of Sunderbans deer in form of trackways (Frey, 1973). These are hoof marks where a pair of laterally displaced marks is 
imprinted on the muddy surface. The hoof marks are characterised by a subelliptical depression with a central ridge along the direction of locomotion. The hoofs are 8 to $10 \mathrm{~cm}$ long and 5 to $6 \mathrm{~cm}$ broad. The stride is 55 to $60 \mathrm{~cm}$. Fig. 5 shows three sequential pair of hoof impressions (six foot-print casts of Sunderbans deer, Axes axes) indicating the direction of movement of the track maker.

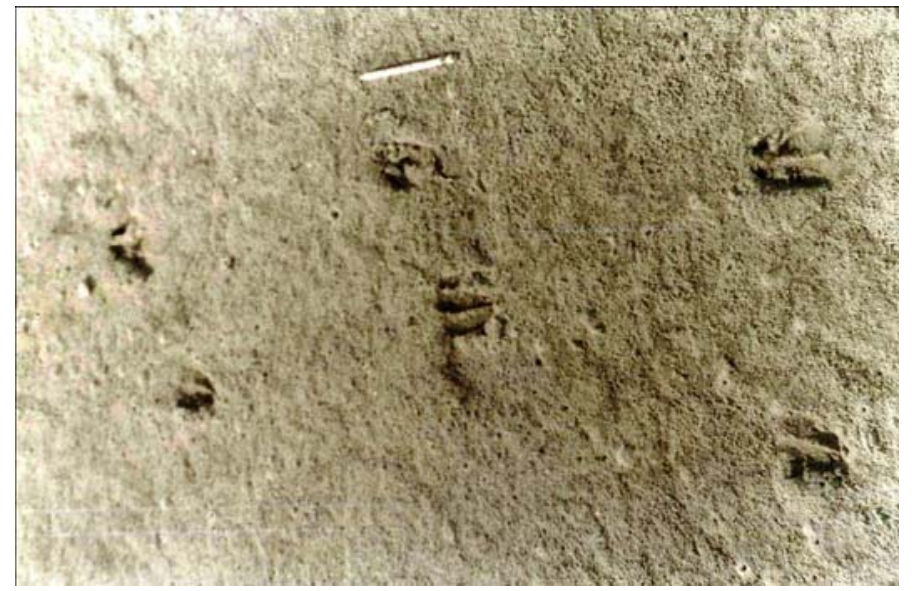

Fig. 5: Three sequential pair of hoof impressions of the Sunderbans deer, Axes axes. Pencil is $15 \mathrm{~cm}$.

\section{Foot Prints of Royal Bengal Tiger (Panthera tigris)}

The upper mudflat of the Bulchery Island revealed a rare exhibit of the Royal Bengal Tiger foot print in association with some other quadruped (Fox/Large Mongoose) foot imprints (Fig. 6). As a single foot print of the tiger was present on the mudflat, it was not possible to measure the stride and pace of the track maker. The imprint is 24 to $25 \mathrm{~cm}$ long and 14 to $16 \mathrm{~cm}$ wide with five distinct impressions of the paw. The rectangular nature of the large impressions and the elongated nature of the finger prints indicate that the animal was a female one. Sarjeant (1975) has given an elaborate description of vertebrate foot prints together with their implications in determining the nature of movement i.e. walking or racing manner.

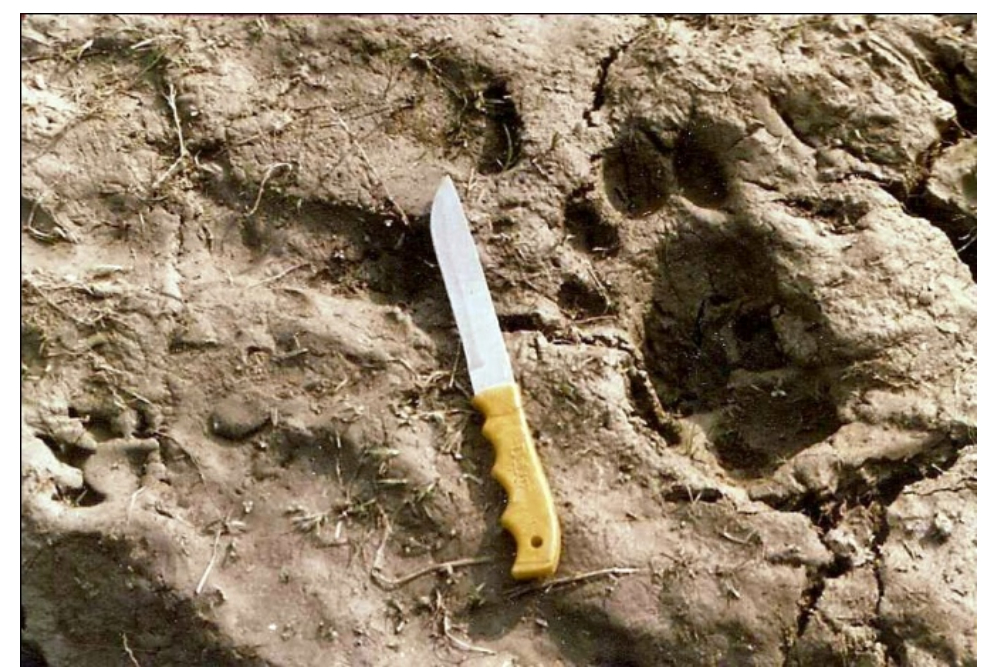

Fig. 6: Tiger footprint in association with other quadrupade (fox/large mongoose) foot impression. Knife is $26 \mathrm{~cm}$ 
Open access e-Journal

Earth Science India, eISSN: $0974-8350$

Vol. 9 (I), January, 2016, pp. 1 - 20

http://www.earthscienceindia.info/

\section{Ecological Importance of Foot Prints}

The Sunderbans Biosphere Reserve is the abode of several vertebrate and invertebrate animals. This complex ecosystem is also characterised by a network of food webs where the flow of energy in terms of predator-prey relationship is well documented by a number of workers (Sanyal, 1994; Chakraborty, 1994). The close association of the imprints of Sunderbans deer and that of the Royal Bengal Tiger revealed a unique predator-prey relation which is worked out from sedimentological stand point. Thus, the importance of study of bioturbation is not only restricted to animal-sediment interactions, this study also helps understanding the transference of energy in the food chains of the inhabiting animals.

\section{Crawling Traces: Trail marks left on sediments due to locomotion of organisms.}

These are continuous grooves produced during locomotion of the animals having part of their bodies in contact with the substrate surface. They may also appear as some subsurface traces made by animals moving from one place to another. The tracks are formed by walking bristles, other appendages or due to muscular movement of the body both on sandy and muddy substrates. It has been observed that the same animal performs different movement patterns like walking, cantering or galloping and creates different crawling traces (Simpson, 1975).

The muddy surface of the mid channel bars and point bars of the Hooghly-Matla estuarine complex are profusely marked by sinuous crawling traces of Telescopium telescopium. These traces continue for over $300 \mathrm{~cm}$ in many instances. Width of traces corroborates with the animal width at its base which ranges from 3 to $5 \mathrm{~cm}$. The locomotive trace of Telescopium telescopium registers a gradual tapering towards its distal end (Fig. 7).

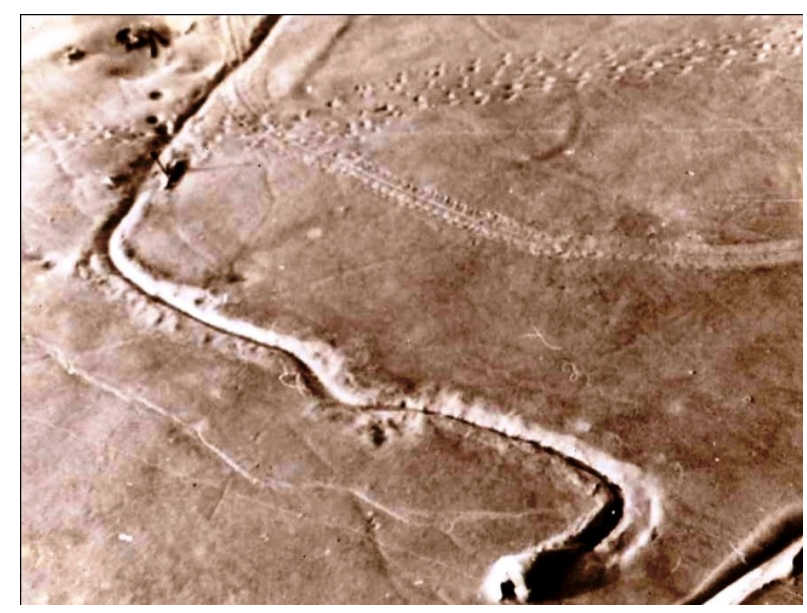

Fig. 7: A sinuous crawling trace of a living Telescopium telescopium on the mudflat of marginal bar. A trailmark of Carcinoscorpius sp. is seen farther northeast of the photograph. Knife is $26 \mathrm{~cm}$.

The mud skippers Boleophthalmus sp., on the contrary, make a number of straight to slightly wavy traces that radiate from a central burrow opening often used as refuge (Fig. 8). These traces are produced by the movement of the ventral part of animal body during locomotion. A series of biserial pectoral fin marks also ornament the central markings from 
two sides. The traces make jumbled mess around the central burrow. The traces of Cerithidea sp. may impart further complications in the architecture. In other instances, sinuous, elongate trails of certain unknown gastropods characterise the mudflat of Thakuran River particularly on the creek margins. These markings are sinuous grooves on muddy surface and promote draining of interstitial water.

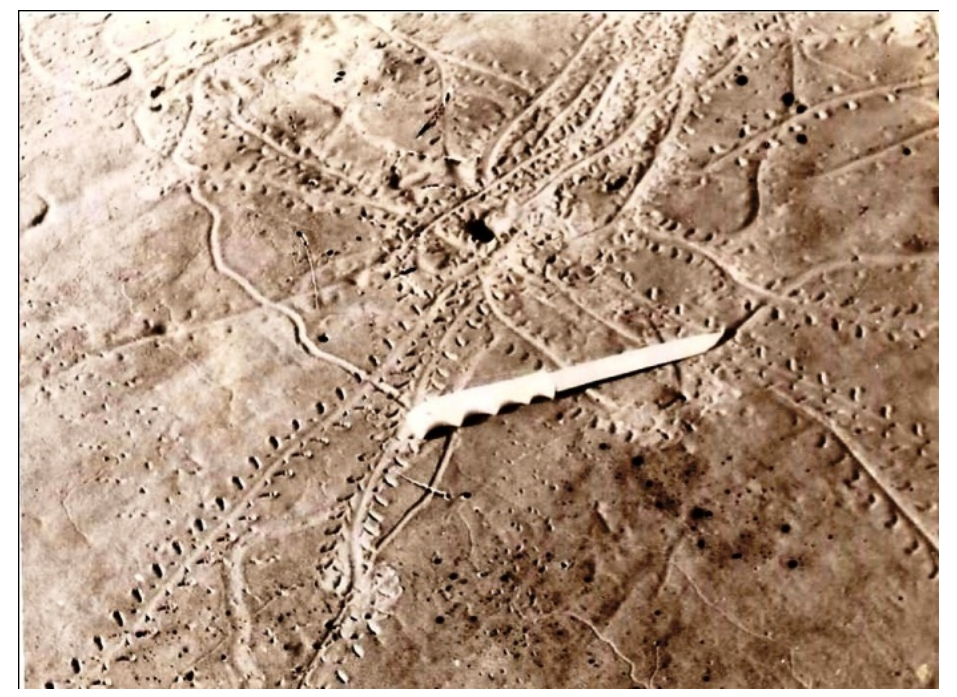

Fig. 8: A burrow of mud-skipper along with its radiating crawling tracks. A series of biserial pectoral fin marks are arranged on both sides of the central markings. Juxtaposed with these crawling traces are the grazing traces of Cerithidea cingulata.

Crawling traces and trails are also frequent on the sand flats of swash platforms and mid channel bar surfaces. Fig. 9 exhibits the trace of a gastropod commonly known as moon shell (Polinices sp.) on the sandy swash platform of Bakkhali. The animal is seen to rest at the end of the trace and the trace is formed during locomotion of the animal. The central groove with elevated ridges on either side leaves a sandy rail on the surface.

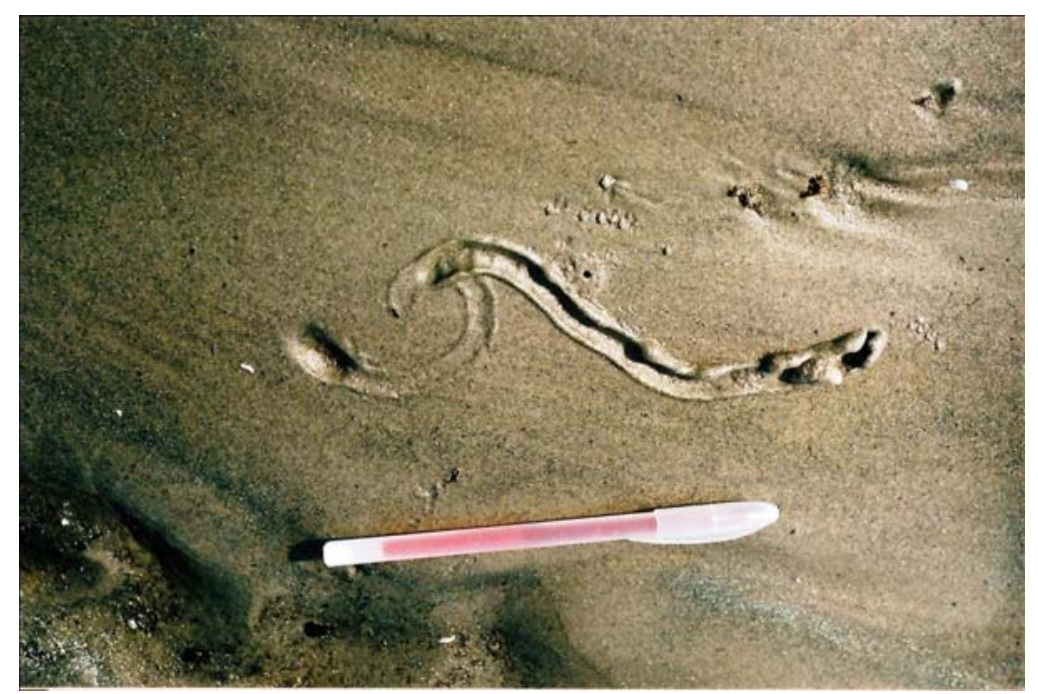

Fig. 9: Crawling trace of the moonshell Polinices sp. (Gastropod) on the sandflat of swash platform. The animal is seen at the end of the trace. The marginal ridges are quite prominent. The pen is $15 \mathrm{~cm}$. 
Open access e-Journal

Earth Science India, eISSN: $0974-8350$

Vol. 9 (I), January, 2016, pp. 1 - 20

http://www.earthscienceindia.info/

\section{Browsing traces: Marks left over by organisms feeding on sediment surface.}

These traces are formed by excavations made by deposit feeders while in search of food within or on the sediment surface. A radial pattern is formed during browsing of Metaplax sp. Radially arranged browsing traces vary in number from 2 to 6 in many instances. The traces diverge from a central burrow and are straight to slightly wavy in nature. On the other hand, browsing traces formed by Carcinoscorpius rotundicauda (King crab) are loop-like to very irregular. Very fine ridges and grooves run within the trace boundaries. Width of the browsing traces is dependent on the width of the animal responsible to create the markings. As the grooves are deep enough in most occasions, they have high preservation potential and can be obtained from ancient rock records in the form of sole marks at the bottom of overlying sedimentary unit. Browsing scratches on sediment surface further augment draining of interstitial water in the form of fine rills at late stage emergence.

\section{Grazing Traces: Marks left over on sediments depending on grazing behaviour.}

Grazing traces are often made by the gastropods. The traces are shallow to deep on sediment surface depending on the size and weight of the grazers. The traces are sinuous and vary in length from one centimetre to tens of centimetres. Generally 'herd' of Cerithidea cingulata grazing on the algal mats of mudflats impart a surface roughness. Assemblage of several grazing marks imposes a complex mess on the sediment surface. Occasionally, 'nibbing' by Cerithidea sp. terminates abruptly at the sharp edge of algal mats. Crawling traces of Telescopium telescopium and resting refuge of Anadara sp. introduce more bed roughness (Fig. 10). These animals are closely associated with Cerithidea sp. move parallel to create parallel markings. The animals rest at the end of each groove and this helps identifying the direction of movement of the animals.

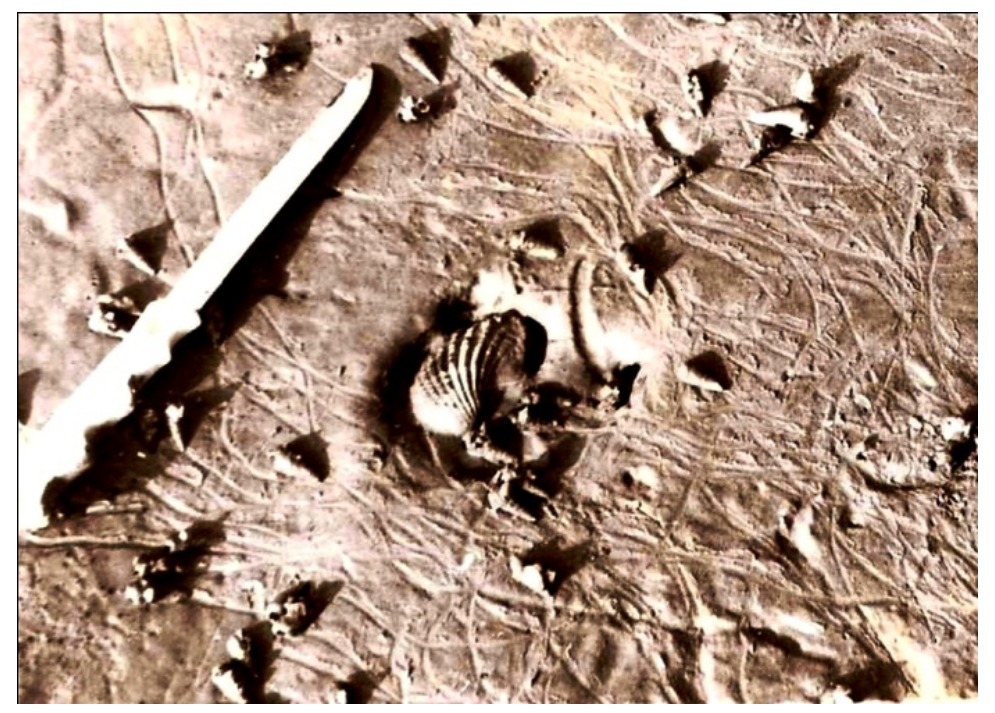

Fig. 10: An Anadara granosa is at rest on the mudflat. Nibbing of Cerithidia sp. makes a mess all around. Note the random orientation of Cerithidea cingulata. Knife is 26 $\mathrm{cm}$.

Among the grazers, the amazingly fast moving ghost crabs Ocypode macrocera constitute a very important community. They produce surface roughness by making grazing scratches and heaping pellets on sand flats. 
It is worth mentioning in this connection that although algal mats help restoring stabilization of sediment surface biogenic scratching, nibbing and grooving destabilize textural bondage. This is well exhibited by the various grazing marks produced by the deposit feeders on the intertidal sand and mudflats.

\section{Resting Traces: Marks left behind by organisms resting at a place on sediment surface}

These impressions are produced by animals while they are at rest on sediment surface. Resting traces of hard molluscan shells are common. Fig. 11 exhibits impression of a valve of Anadara granosa on the mid channel bar mudflat surface of Thakuran River. The valve impression is $3 \mathrm{~cm}$ long and $2.6 \mathrm{~cm}$ wide. The quadrangular shape of the valve with radial growth lines is clearly seen. The left portion of the impression is superimposed by the fin marks of Boleophthalmus sp.

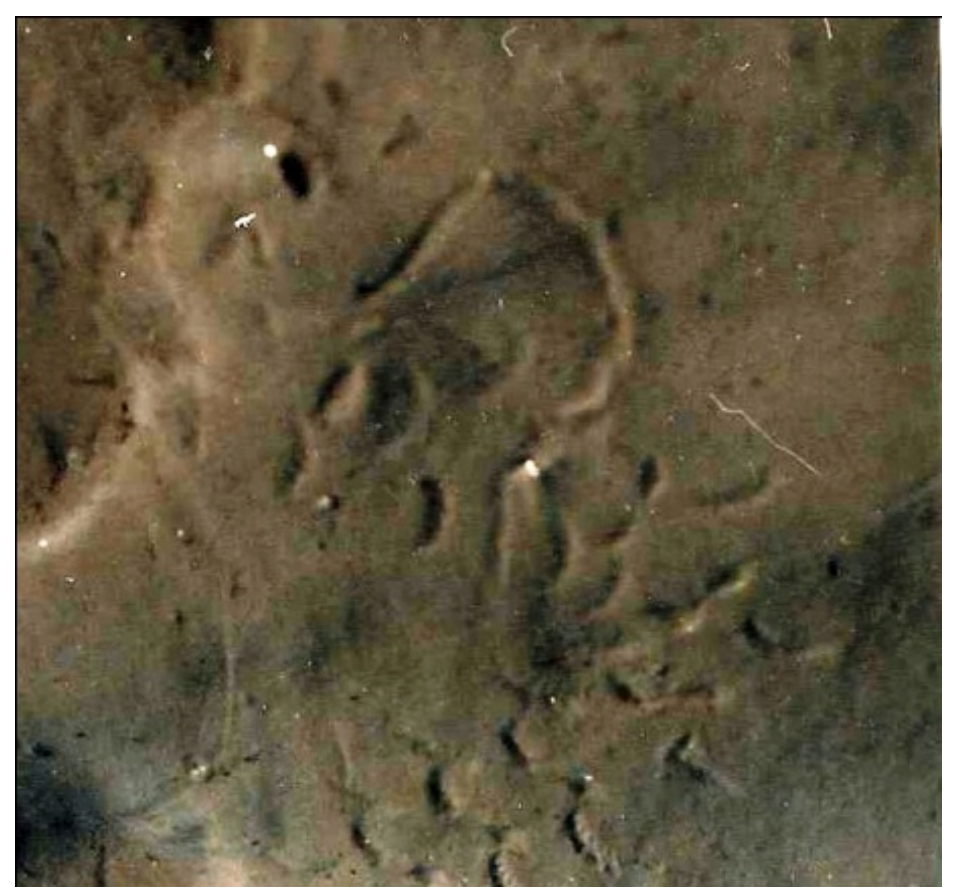

Fig. 11: Impression of one of the valves of Anadara granosa on the mudflat of mid-channel bar. The animal has left the place leaving only the impression. Fin marks of Boleophthalmus sp. are seen on the left of the Anadara impression.

In some instances scours are formed around the resting place of the animals due to circulatory motion of tidal water. Eventually the animals get incised on the sediments or may lie in some depression. The close association of Cerithidea sp. and Anadara sp. or Boleophthalmus sp. and Anadara sp. together with their functional markings help interpreting the paleoecology when the animals and their activities are preserved properly.

The other resting trace of importance on the muddy point bars of tidal creeks is of Carcinoscorpius rotundicauda (king crab). The animals are quite big in size. Their length ranges from 15 to $20 \mathrm{~cm}$ and breadth is from 12 to $15 \mathrm{~cm}$. The telson length is of about 20 $\mathrm{cm}$. The impression of margin of the animal together with the whole or part of the telson impression in the form of a linear depression is often well preserved on the muddy surface (Fig. 12). 
Open access e-Journal

Earth Science India, eISSN: $0974-8350$

Vol. 9 (I), January, 2016, pp. 1 - 20

http://www.earthscienceindia.info/

The resting traces may be changed over to dwelling structure depending on the change in the mode of activities of the animals (Osgood, 1970). Fig. 12 exhibits the burrowing activity of Carcinoscorpius sp. where the sediments are dug out to form surficial mounds.

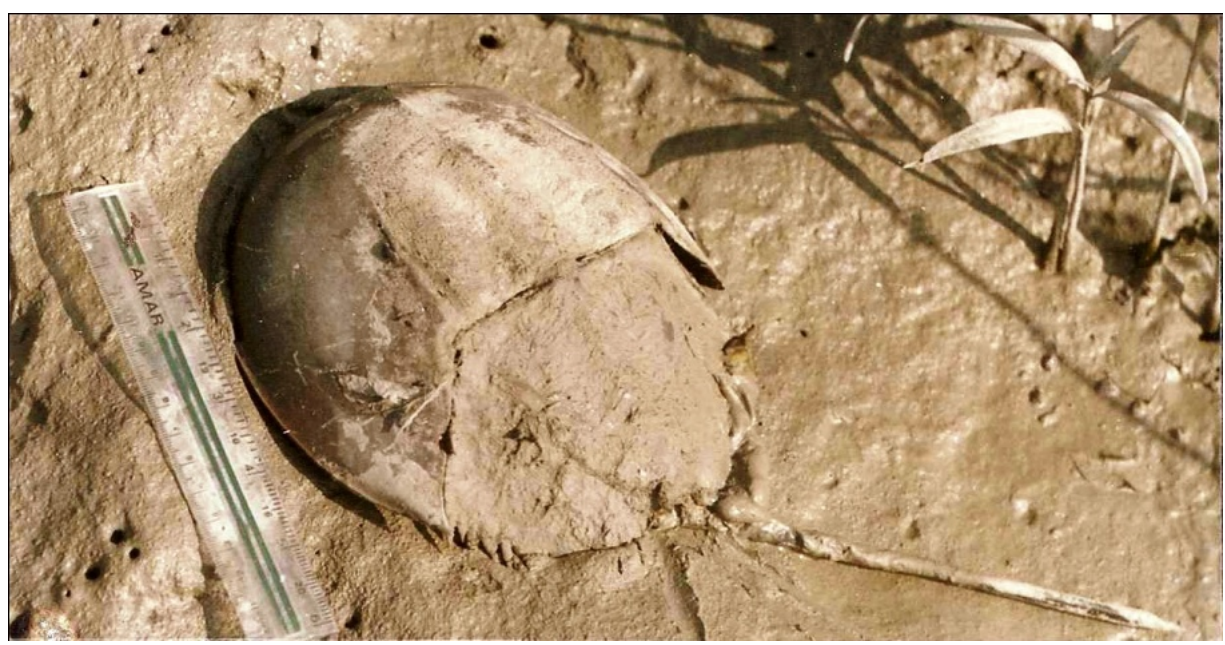

Fig. 12: A Carcinoscorpius rotundicauda (King crab) is at rest on the mud flat. The telson marking is quite prominent. Scale is $15 \mathrm{~cm}$.

Fin Marks: Traces produced by swimmers like fish while moving on sediment surface

Intertidal flat in Sunderbans is very commonly dominated by mud skippers like Boleophthalmus sp. (Gobid Fish). Pectoral fin marks produced by Bolephthalmus sp. are quite common. The well preserved nature of fin marks on muddy surface is supposed to be due to the cohesive nature of mud reinforced by microbes matting. In a different area, on the lower part of a point bar near Damkal, the muddy surface has been left over by numerous shallow and short criss-cross fin marks (?) of some unidentified swimming animals (Fig. 13).

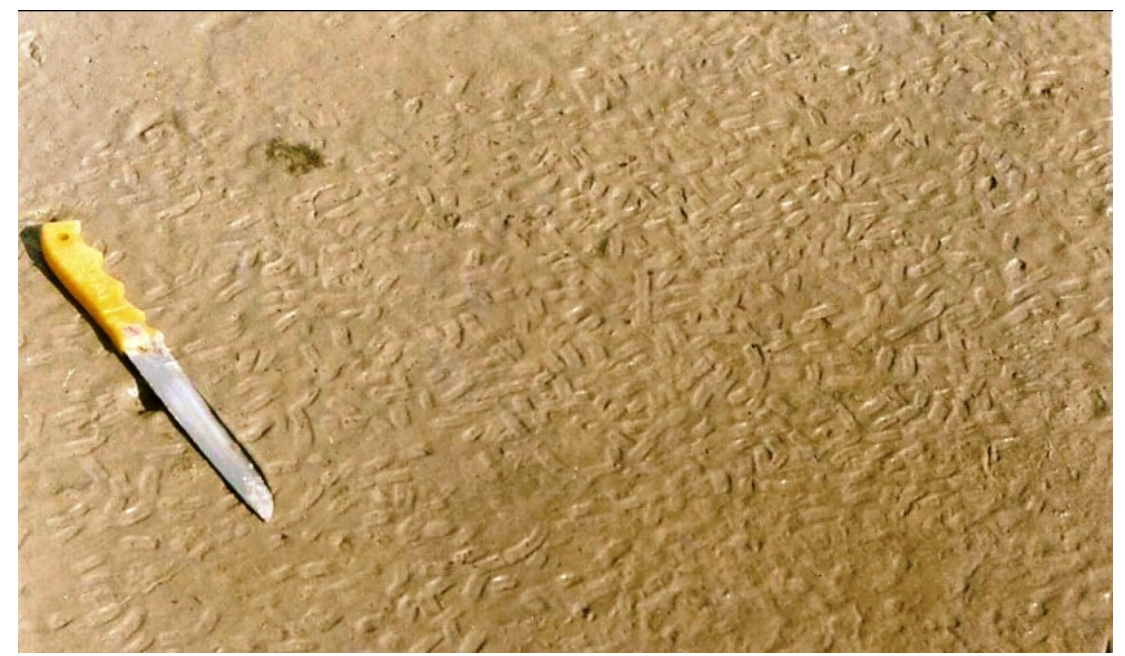

Fig. 13: Short shallow criss-cross fin marks of some unidentified swimmer on the muddy surface of a point bar of the Sunderbans. The knife is $26 \mathrm{~cm}$. 


\section{Mounds: Heaps of granular or pelletoidal materials accumulated at burrow mouths}

These are of variable shapes and sizes. The mounds may be conical domes, regular crater like bodies to irregular in shape. These are generally produced by the ejection of granular or pelletoidal materials at the time of burrowing by ghost shrimps (Thalassina sp.; Fig. 14) and fiddler crabs (Uca sp.). The mounds are commonly observed on mud flats of the upper intertidal zone. The mound materials are mostly muddy $\left(\mathrm{M}_{\mathrm{Z}}=6.12\right.$ to $\left.6.40 \mathrm{phi}\right)$. Fig. 14 exhibits a small domical mound (dia: $13 \mathrm{~cm}$; ht: $6 \mathrm{~cm}$ ) formed by a ghost shrimp at Dhanchi mid channel bar. The mound slopes uniformly on all sides from its apical region having a central exhalation pit. Close to this mound, a separate pit at the centre of a depression is also seen clearly. This pit is perhaps used for inhalation purposes.

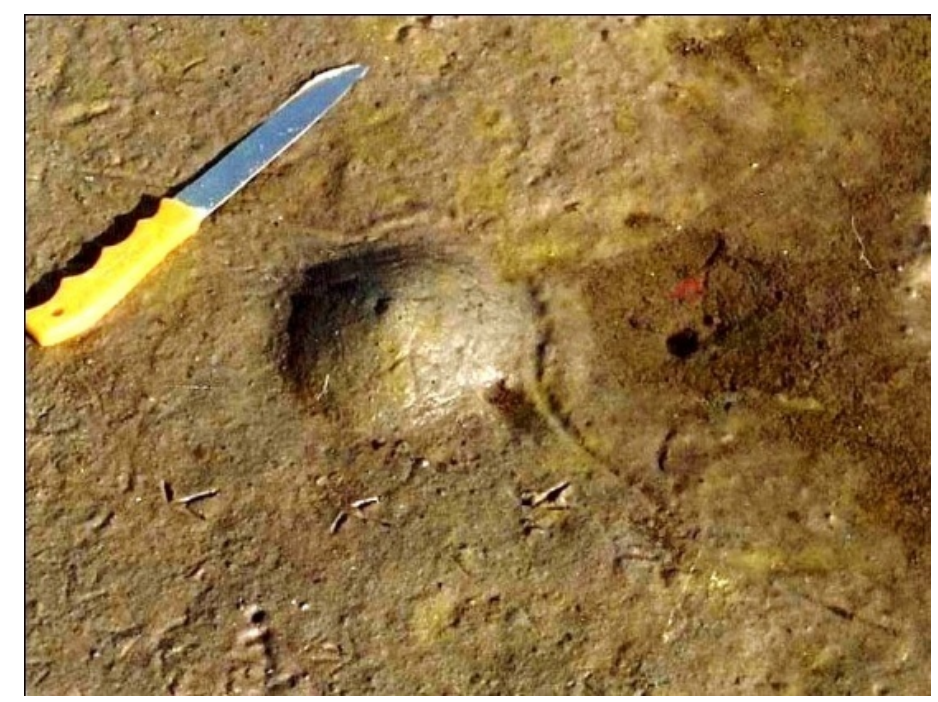

Fig. 14: A small domical shrimp mound with a central pit at the apex. Note a separate pit at the centre of a nearby depression. Algal matting is clearly visible on the mudflat. Knife is $26 \mathrm{~cm}$.

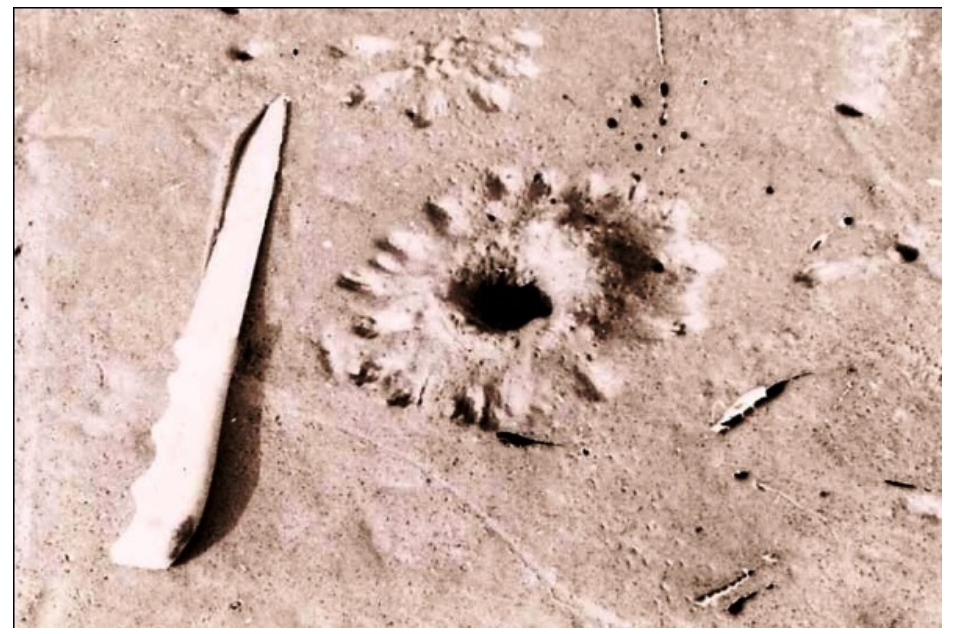

Fig. 15: Crater-like mound around exhalent burrow opening of Metaplax crenulata on the mudflat. Note the flowering pattern around the burrow. The peripheral discontinuity is due to the movement of the animal from the burrow opening to all directions. 
Open access e-Journal

Earth Science India, eISSN: $0974-8350$

Vol. 9 (I), January, 2016, pp. 1 - 20

http://www.earthscienceindia.info/

Some mounds of fiddler crab, Metaplax crenulata form a typical crater-like structure with a central opening. In many occasions these crater mounds are discontinuous at their peripheral margin and this is due to removal of mound material along the paths of movement of the animal from the burrow-mouth in all directions (Fig. 15).

The burrower crustaceans thus act as agents for recycling sediments both laterally and vertically. The net sediment budget remaining same, the intertidal materials show thorough mixing in and around the burrows. Biogenic subduction (Aller, 1982) is always associated with the process of burrowing.

\section{Internal Bioturbation Structure}

Internal bioturbations are impressions produced within the sediments and are formed mainly by animals living in and/or free moving within sediments. They are more prominent in tidal mud flats of both accretionary point bars and mid channel bars.

\section{Press Structures: Impressions produced by animals having restricted movements in and around the place of their dwelling within the sediments.}

Press structures are rather rarely observed as the animals producing such structures do not leave much surface indications. However, this structure is well exhibited by Macoma sp. in the mudflats of point bars and mid channel bars. Macoma sp. makes more or less vertical siphonal burrows of few millimetre diameters and produces press marks at a depth of 40 to 45 $\mathrm{cm}$ where they rest. Their presence at depth is evidenced by a flowery structure around their siphonal burrow formed during grazing by the siphons.

Dwelling Structures: Burrows and tubes made by organisms in which they live or escape.

Bioturbational activities during digging are performed for the purpose of i) dwelling and escaping and ii) feeding. The dwelling and escaping burrows are generally simple, straight or ' $U$ ' shaped- whereas, feeding burrows are much more complicated (Seilacher, 1954). The dwelling structures can be of three types:

\section{Borings: Burrows in hard substrates.}

These are observed mostly on dead mangrove trunks or on drifted plant materials that rest on the sediments. The inner parts of the borings made by polychates are generally of 2 to $6 \mathrm{~mm}$ diameter, and often contain hard calcified linings in the inner walls. These borings, in turn, act as refuge for fiddler crabs, brachuran crabs, sea anemones, tube anemones and sea pens.

\section{Dwelling burrows on sand and mud deposits: Used for both dwelling and escaping purposes}

The burrows may be short simple (e.g. of sea pens and sea anemones), straight tubular with coatings of parchment-like materials (e.g. of Polychaetes), unbranched, branched, Y-shaped or U-shaped (e.g. of Ghost crab, Ocypode sp. and fiddler crabs, Uca sp.) the burrows are of variable length $(3.2$ to $8.4 \mathrm{~cm})$ and width $(0.05$ to $3.5 \mathrm{~cm})$. The insect like Heterocerus sp. (Coleoptera) creates very narrow, sinuous to intricately complex 'tunnels' on intertidal muddy surface (Fig. 16). A detail list of the macrobenthic burrowing animals and the nature of burrows made by them are given in Table- 2 . 
The sand flats of mid channel bars and swash platform near the river mouth register profuse bioturbational activities. The animals disturb the deposits both internally as well as surficially. The dwelling burrows of ghost crabs (Ocypode macrocera) heavily disturb the internal laminations and create a number of surface structures both by ejecting injested sandy materials and pelletization.

Digging operations by Ocypode macrocera in the upper intertidal sand flat of the Dhanchi mid channel bar are often seen during low tides (Fig. 17). The animals strike the sandy substratum repeatedly to impose a quick sand property to the sediments for purpose of digging. These areas are commonly strewn by numerous spherical sand pellets of 8 to $10 \mathrm{~mm}$ diameter.

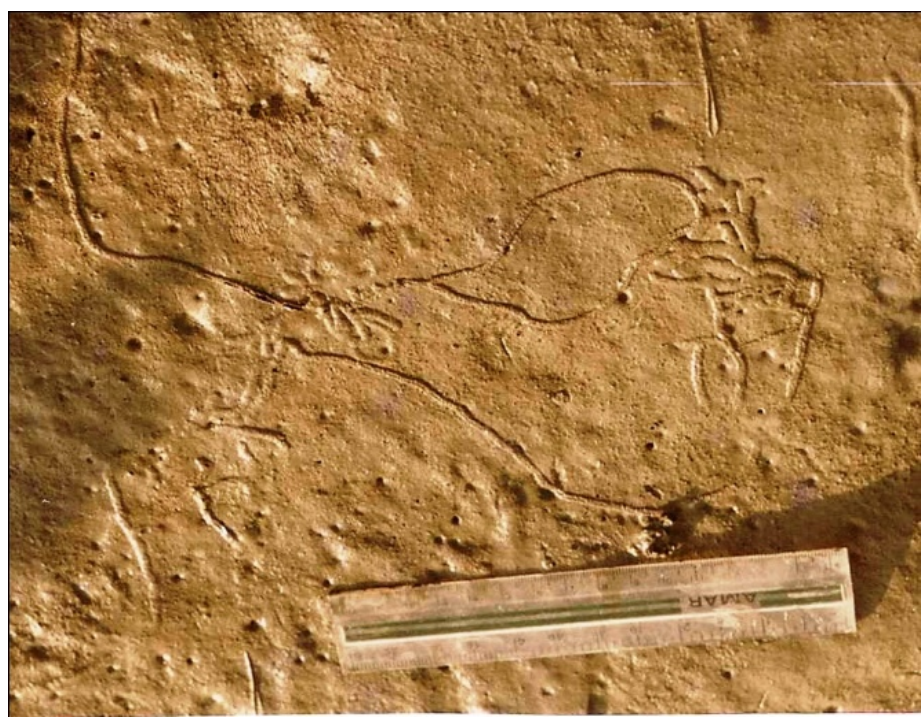

Fig. 16: Intricate and narrow tunnels of Heterocerus sp. on the mudflat. Rular is $15 \mathrm{~cm}$.

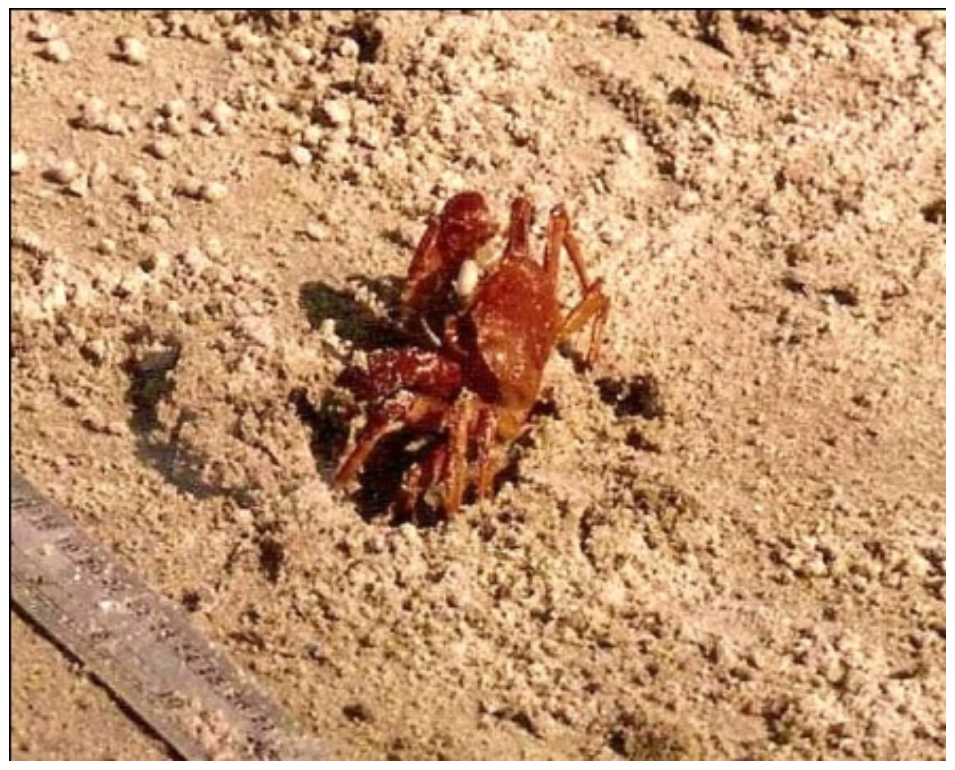

Fig. 17: Digging operation by ghost crab Ocypode macrocera on the intertidal sandy surface of mid-channel bar. The surface is strewn with numerous pellets. 
Open access e-Journal

Earth Science India, eISSN: $0974-8350$

Vol. 9 (I), January, 2016, pp. 1 - 20

http://www.earthscienceindia.info/

Table-2: List of macrobenthic burrowing animals and the burrow characters in the deposits of Hooghly-Matla estuarine complex.

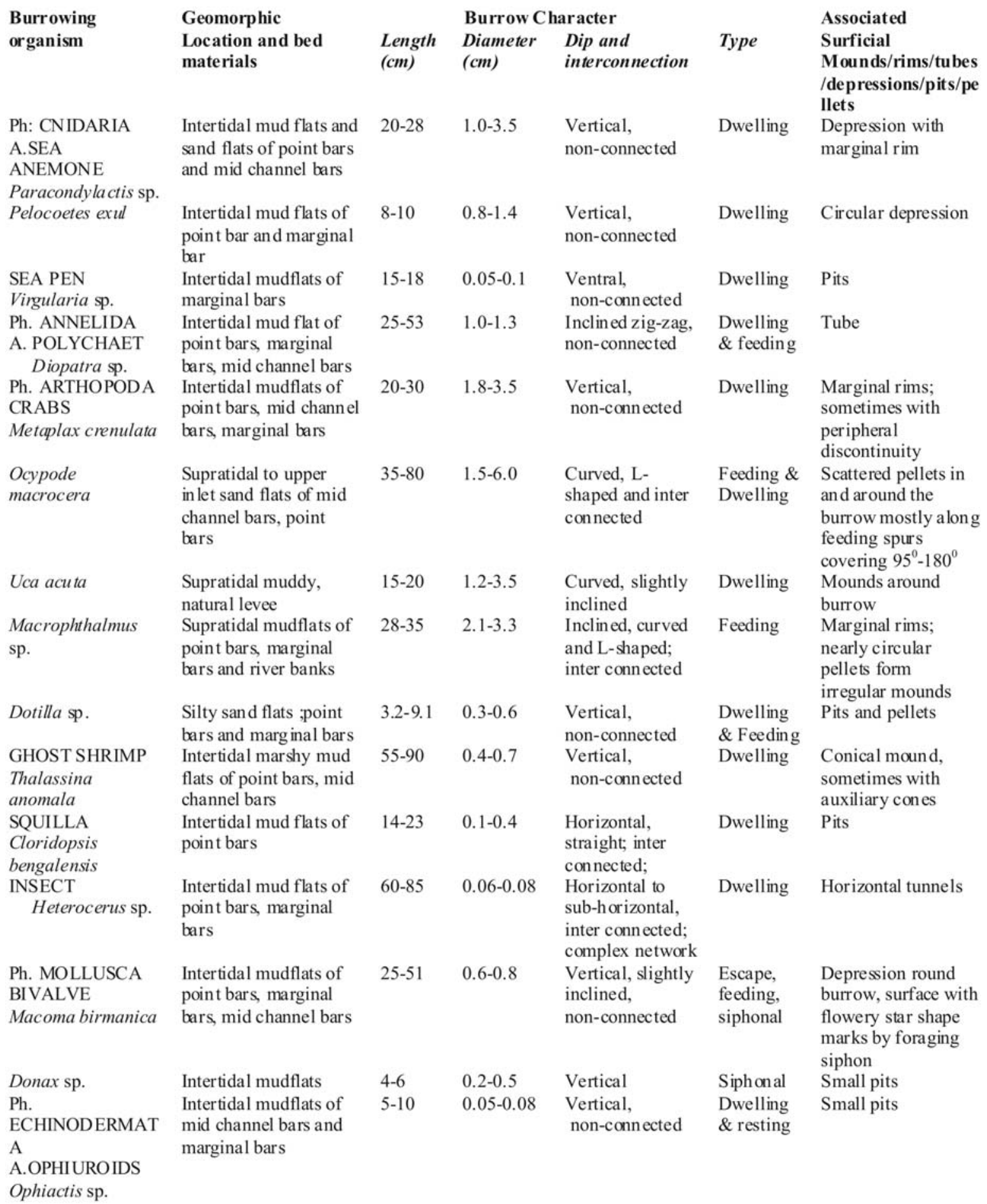


In many instances, radially extended feeding spurs are formed on the surface during feeding of Ocypode sp. The spurs cover $95^{\circ}-180^{\circ}$ arc of a circle. The feeding lines are straight and extend up to $50 \mathrm{~cm}$ (Fig. 18). Clots of ingested materials ejected by the crabs in their process of feeding and digging are relatively large and without any well-defined shape. These clots mark the outer limits of the feeding zone. In many instances intensive burrowing by crab gives a very complex mottled look to the bank sediments (Fig. 19).

The fiddler crab, Uca sp. acts as a very important agent of bioturbation. They make tubes of granular aggregation of mud. The tubes are often exposed $2 \mathrm{~cm}$ above the ground level. Thickness of the tube walls varies from 3 to $5 \mathrm{~mm}$; diameter ranges from 0.8 to $1.0 \mathrm{~cm}$. The tubes often collapse by tidal action and the tube-building granules remain scattered around the centre of the tubes.

Sandy intertidal zone sediments are often manipulated by Ophiactis sp. (Echinoderm) which may penetrate some 10 to $12 \mathrm{~cm}$ below the surface. They produce very narrow $(<3 \mathrm{~mm}$ diameter), straight vertical burrows. The burrows are parallel to each other and are essentially restricted to the muddy zone.

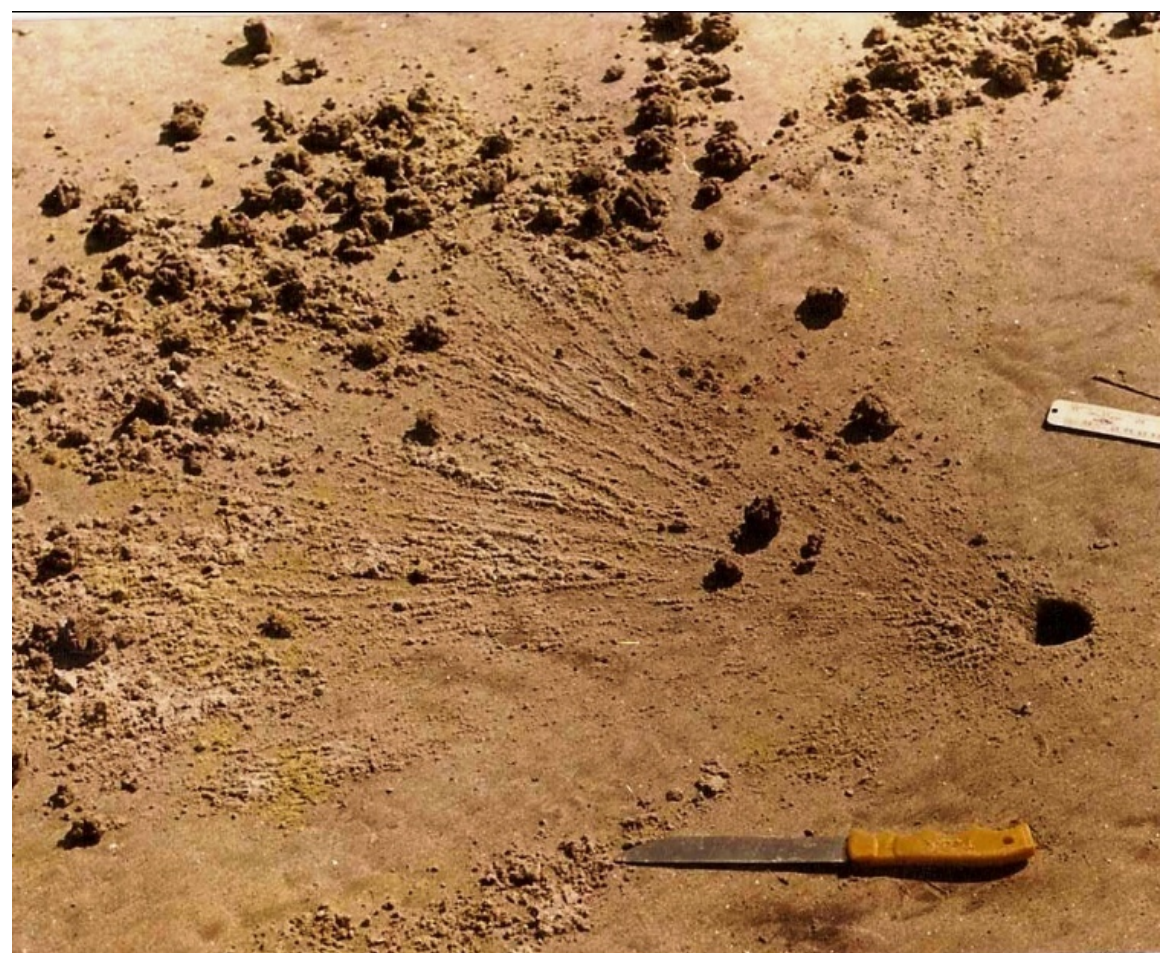

Fig. 18: Radially extended feeding spurs of Ocypode macrocera on the sand flat. Burrow opening and ejected pellets are clearly seen. Knife is $26 \mathrm{~cm}$.

The role of polychaetes such as Nereis sp., Perinereis sp. and Diopatra cuprea create semi-permanent dwelling tubes of variable length $(15$ to $30 \mathrm{~cm})$ and diameter $(3 \mathrm{~mm}$ to $5 \mathrm{~cm}$ ) in the intertidal mudflats. Generally these semi-permanent tubular bodies are made up of fine sand and mud with very small pieces of shells and organic debris cemented together by mucus materials. In many instances, the exposed portions of the tubes remain intact above the surface and stand as obstacles on the path of moving water. 
Open access e-Journal

Earth Science India, eISSN: $0974-8350$

Vol. 9 (I), January, 2016, pp. 1 - 20

http://www.earthscienceindia.info/

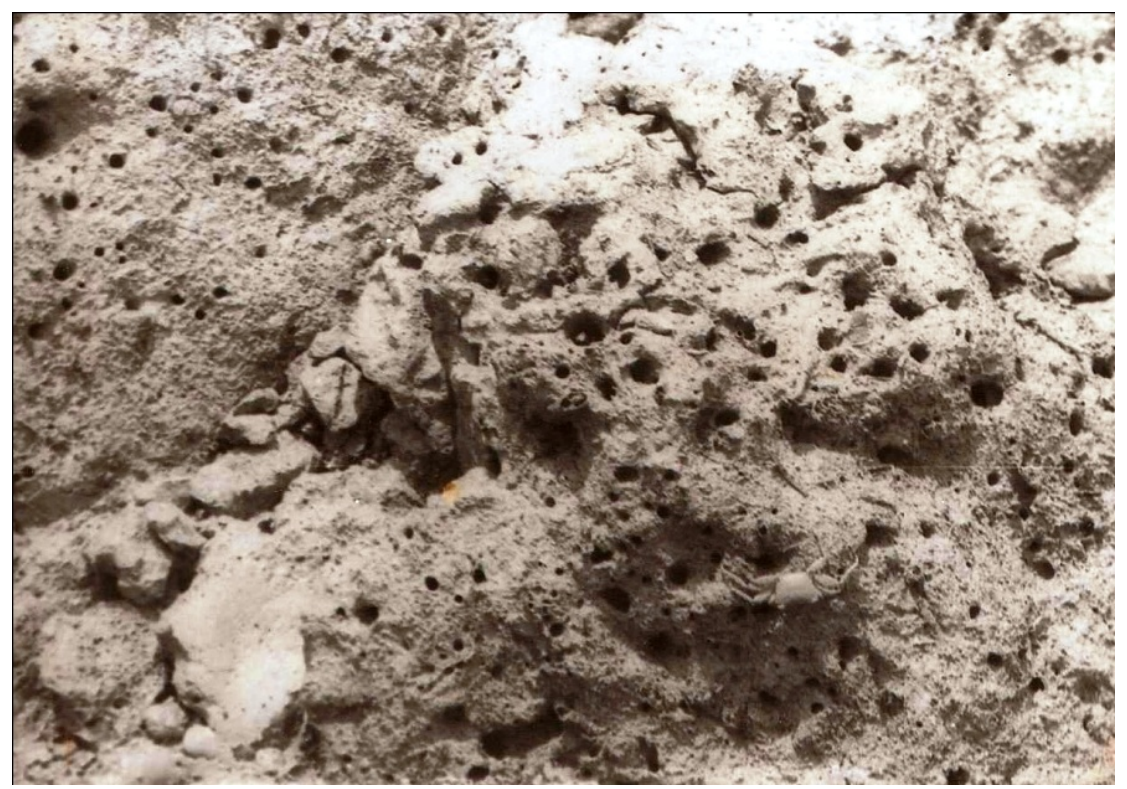

Fig. 19: Mottling of mud bank due to profuse bioturbation by crab burrows.

\section{Feeding Burrows: Interconnective burrows made by animals for purpose of feeding}

These are often complicated in pattern. Sometimes the deposits are mottled by numerous burrows of 5 to $40 \mathrm{~mm}$ diameter. Length of burrows is often difficult to measure because of their frequent interconnections. At Dhanchi, the supratidal mud bank exhibits cluster of rejected food pellets of Macrophthalmus sp.

\section{Discussions}

Dwelling structures, feeding structures and internal bioturbation structures have profound role in churning the mudflat and sand flat sediments. An overall mixing of sediments takes place very commonly and this alters the textural properties of sediments deposited by physical processes. The primary depositional behaviour of sediments produced by swash-backwash (waves) effects and by tidal currents is manipulated largely by different intensities of biogenic activity. Net sediment budget of sand and mud flats remaining constant, burrowing leads to both lateral and vertical exchange of sediments and biogenic subduction of surface topography. The internal laminations are disturbed to different degrees and are deformed by folding and microfaulting. The ejected burrow materials in the form of mounds, castings and projected tubes commonly create complications in the surface flow pattern and flow directions. Flow divergence against these mounds and obstacles becomes responsible for the generation of current crescents and modification of bedforms.

\section{References}

Aller, R.C. (1982) The effects of macrobenthos on chemical properties of marine sediments and overlying water. In: McCall, P.Z. and Tevesz, M.J.S (eds.) Animal Sediment Relations, Plenum Press, New York. pp. 53-102.

Basan, P.B. and Frey, R.W. (1977) Actual palaeontology and neoichnology of salt marshes near Sapelo Island, Georgia, In: T.P. Crimes, and J.C. Harper (eds.) Trace fossils 2, Geol. J. Spec. Issue 9, Seel House Press, Liverpool, England, pp.41-70. 
Chakraborty, K. (1994) Biodiversity of mangrove ecosystem of Sunderbans. In: S. Maity, and N. Mukherjee (eds.), Bidhan Chandra Krishi Viswavidyalaya Publ., pp. 57-64.

Das, G.K. (2015) Estuarine Morphodynamics of the Sunderbans. Coastal Research Library. Vol. 11. Springer, Switzerland, 211p.

Dorjes, J., Gadow, S., Reineck, H.E. and Singh, I.B. (1969) Die Rinnen der Jade (Sudiche Nordsee). Sedimente and Makronenthos, Seckenbergimana Marit., v. 1, pp. 5-62.

Frey, R.W. (1973) Concepts in the study of biogenic sedimentary structures. J. Sediment. Petrol., v. 43, pp. 619.

Frey, R.W. (1975) The realm of ichnology, its strength and limitations. In: R.W. Frey (ed.) The Study of Trace Fossils. Springer-Verlag, pp. 13-38.

Frey, R.W. and Howard, J.D. (1969) A profile of biogenic sedimentary structures in a Holocene barrier island salt marsh complex, Georgia, Gulf Coast. Assoc. Geol. Socs., Trans., v. 19, pp. 427-444.

Hertweck, G. (1970) The animals community of a muddy environment and the development biofacies as effected by the life cycle of the charaeteristic facies. In: T.P. Crimes and J.C. Harper (eds.) Trace Fossils, Geol. J. Spec.Issue, 3, pp. 235-242.

Hertweck, G. (1975) Recent biocoenoses and ichnocoenoses in shallow water marine environments. In: Frey, R.W. (ed.) The study of trace fossils. New York. Heidelberg, Berlin, Springer, pp. 468-491.

McCall, P.L. and Tevesz, M.J.S. (1982) Animal Sediment Relations. Plenum Press. New York, London, 336p.

Osgood, R.G., Jr. (1970) Trace fossils of the Gincinnat area. Palaeontographica Amer., v. 6(41), pp. 281-444.

Paterson, D.M. Crawford, R.M. and Little, C. (1986) The structure of benthic diatom assemblages: a preliminary account and evolution of low temperature scanning electron microscopy. J. Exp. Mar. Biol. Eco., v. 96, pp. 279-289.

Raffaelli, D. and Hawkins, S. (1996) Intertidal Sediments. Chapman and Hall, London, 356p.

Reineck, H.E. (1958) Wiihlban-Gefiige in Abhangigkeit von sediment - Umlagerungen. Senckessbergiana Leth., v. 39, pp. 1-23.

Reineck, H.E. (1967) Parameter von Schichtung und Bioturbation. Geol. Rundschan. v. 56, pp. 420-438.

Reineck, H.E. and Singh, I.B. (1980) Depositional Sedimentary Environments. Springer Verlag, New York, 408p.

Richter, R. (1936) Marken and spuren in Hunsruckschiefer II. Schichtung und Grundleben. Senckenbergiana, v. 18, pp. 215-244.

Richter, R. (1937) Marken and spuren aus allen Zeiten I-II. Senckenbergiana, v.19, pp. 150-169.

Richter, R. (1952) Fluidal-Textur in Sediment-Gesteinen und uber Sediflukton uberhaupt Notizbl. Hess. Landesamtes Bodenforsch. Wiesbaden, v. 5, pp. 67-81.

Sanyal, P. (1994) Mangrove distribution in Indian Sunderbans. In: S. Maiti, and N. Mukherjee (eds.), Bidhan Chandra Krishi Viswavidyalaya Publ., W.B. pp. 36-40.

Sarjeant, W.A.S. (1975) Fossils tracks and impressions of vertebrates. In: R. W. Frey (ed.) The study of trace fossils. Springer - Verlag. pp. 283-324.

Schmidt, H. (1958) Zur Rangordnung der Faziesbegriffe. Mitt. Geol. Ges. Wien. v. 49, pp. 333-345.

Seilacher, A. (1953) Uber die methoden der Palichnologie. 1. Studien Zur Palichnologie. Neues Jahrb. Geeol. Palaont., Abh., 96, pp. 421-452.

Seilacher, A. (1954) Die geologische Bedeutung fosiler. Lebensspuren. Zeitschr. Dentsche Geol. Gesellsch., v.105, pp. 215-227.

Seilacher, A. (1958) Zur 'O’ kologischen characteristic von Flysch und Molasse. Eclogae Geol. Helvetiae, v.51, pp. 1062-1078.

Seilacher, A. (1964) Biogenic Sedimentary Structures. In: J. Lmbrie and N.D. Newell (eds.) Approaches to palaeoecology. New York, John Wiley, pp. 296-316.

Simpson, S. (1975) Classification of trace fossils. In: R.W. Frey (ed.) The study of trace fossils. SpringerVerlag, pp.39-54.

(Received: 02.11.2015; Accepted: 18.12.2015) 